\title{
Life history patterns of Pseudalibrotus litoralis (Crustacea: Amphipoda) on the inner continental shelf, SW Beaufort Sea
}

\author{
Michel A. Boudrias*, Andrew G. Carey, Jr \\ College of Oceanography, Oregon State University, Corvallis, Oregon, 97331 USA
}

\begin{abstract}
Life history traits of Pseudalibrotus litoralis from ice, water column, and sediment habitats were measured in the laboratory. Length-frequency distributions were bimodal, separating juveniles from adults. Temporal variability of population structure in the ice habitat was analyzed with 2-sample Kolmogorov-Smirnov tests. Large differences existed in the number and size of juveniles and adults through time in the ice habitat. These temporal trends, the bimodal population structure, and the level of maturity of adults and immatures all indicate that $P$. litoralis has a 2 yr life cycle. The non-significant difference in population structure between the 3 habitats, and the low abundance in sediments during the spring, suggest the presence of only one population of this lysianassid. The annual maximum of growth rate of adults and immatures, the peaks in the percentage of mature females, and the decrease and stabilization of the sex ratio coincided with the spring maximum of primary production in the ice. Results suggest that this amphipod uses the ice and its early spring carbon source as a spawning site and temporary nursery ground for its young and for immatures preparing for fall breeding. Microspatial analysis of population structure between dense amphipod aggregations and standard transect samples revealed large variability within the ice habitat on a given date.
\end{abstract}

\section{INTRODUCTION}

Research beneath landfast and floating pack-ice in the Arctic and Antarctic has revealed abundant microalgae, flagellates, and numerous diatoms (Apollonio 1961, 1965, Andersen 1977, Hsiao 1980, Tsurikov 1980, Sancetta 1981, Horner \& Schrader 1982, Buck \& Garrison 1983, Horner 1985), meiofaunal organisms, particularly harpacticoid and cyclopoid copepods (Montagna \& Carey 1979, Carey \& Montagna 1982, Grainger \& Hsiao 1982, Kern \& Carey 1983), and macrofaunal communities dominated by gammarid and lysianassid amphipods (Barnard 1959, Knox \& Lowry 1977. Griffiths \& Dillinger 1981, Bradstreet \& Cross 1982, Cross 1982, Gulliksen 1984; see Carey 1985 for a review). These amphipod communities are characteristic of the continental shelf benthos and sea ice in the Eastern Canadian Arctic (Steele 1961, Dunbar 1968), over the deeper waters of the Central Arctic Basin

\footnotetext{
- Present address: Marine Biology Research Division, Scripps Institution of Oceanography, A-002, La Jolla, California 92093, USA
}

(Kulikov 1980, Mel'nikov \& Kulikov 1980) and in Chirikoff Basin in the Bering Sea (Thomson 1984). On the inner shelf of the SW Beaufort Sea, gammarid amphipods also dominate the sympagic, or 'within ice' (Whitaker 1977), and sediment habitats (Carey et al. 1984, Carey 1985).

The most abundant amphipod species in all habitats on the shallow shelf of the southwestern Beaufort Sea is Pseudalibrotus litoralis (Krøyer). The genus Pseudalibrotus is also called Onisimus by some authors (e.g. Sainte-Marie 1984). This epibenthic lysianassid is characteristically most abundant in shallow waters (5 to $25 \mathrm{~m}$ ) and on sandy sediments on continental shelves of the Arctic region (Steele 1961, Griffiths \& Dillinger 1981, Carey et al. 1984) though its distribution can extend down to $125 \mathrm{~m}$ in the Western Arctic and even deeper in Central Arctic waters (Mel'nikov \& Kulikov 1980, Carey 1985). On the inner shelf of the southwestern Beaufort Sea, near Narwhal Island, P. litoralis is the only amphipod that is abundant in the sediments, the water column, and the ice (Table 1). This locally unique lifestyle demonstrates the high adaptability of $P$. litoralis. Its dominance of the amphipod assemblage 
Table 1 . Species abundances (no. per $100 \mathrm{~m}^{3}$ ) of benthic amphipods collected at the Narwhal Island study site in spring 1980

\begin{tabular}{lrrrr|}
\hline Species & Ice & Water column & Sediment & Total \\
\hline Pseudalibrotus litoralis & 7719 & 18 & 500 & 8237 \\
Monoculodes borealis & 0 & 0 & 1227 & 1227 \\
Onisimus affinis & 0 & 0 & 477 & 477 \\
Halirages mixtus & 414 & 3 & 11 & 428 \\
Lagunogammarus setosus & 349 & 1 & 34 & 361 \\
Apherusa glacialis & 268 & 1 & 93 & 303 \\
Onisimus plautus & 0 & 0 & 0 & 939 \\
Acanthostepheia malmgreni & 0 & 0 & 68 & 73 \\
Weyprechtia pinguis & 73 & 0 & 45 & 68 \\
Onisimus derjugini & 0 & 0 & 45 & 46 \\
Modiceros borealis & 0 & 0 & 11 & 45 \\
Acanthostepheia incaninata & 0 & 0 & 11 \\
\end{tabular}

may indicate its capability of trading off the high physiological costs (large salinity fluctuations during ice melt, swimming between the habitats) and higher predatory costs (exposure to benthic, pelagic and sympagic predators) associated with the ice habitat for the energetic benefits available from the ice algal bloom and associated meiofauna.

The main objective of this study was to investigate the life history patterns of Pseudalibrotus litoralis populations in the ice, water column, and sediment habitats on the continental shelf near Narwhal Island. We focussed on the spatial variability in population structure among the 3 habitats and on a microscale (i.e. between amphipod patches and standard transect samples) within the ice habitat. We also determined the temporal trends in population structure within the ice habitat and the diel trends in the pelagic zone. Life history patterns were analyzed from changes of length- frequency, maturity of adults, sex ratios and the number of young produced during the spring spawning season.

\section{MATERIALS AND METHODS}

Macrofaunal amphipods were collected from 13 April to 9 June 1980 on the inner continental shelf of the southwestern Beaufort Sea, $0.4 \mathrm{~km}$ seaward of Narwhal Island (Fig. 1). The sediment was poorly sorted, silty, fine sand (97\% sand, $1 \%$ silt, $2 \%$ clay). The water depth was about $7.5 \mathrm{~m}$, and the thickness of the bottom-fast ice was ca $2 \mathrm{~m}$. The site is within the seasonal ice zone of the southern Arctic Ocean. Ice generally covers the continental shelf waters from late September through early June and reaches a maximum thickness of 1.5 to $2.0 \mathrm{~m}$ in mid-May (Carey et al. 1984).

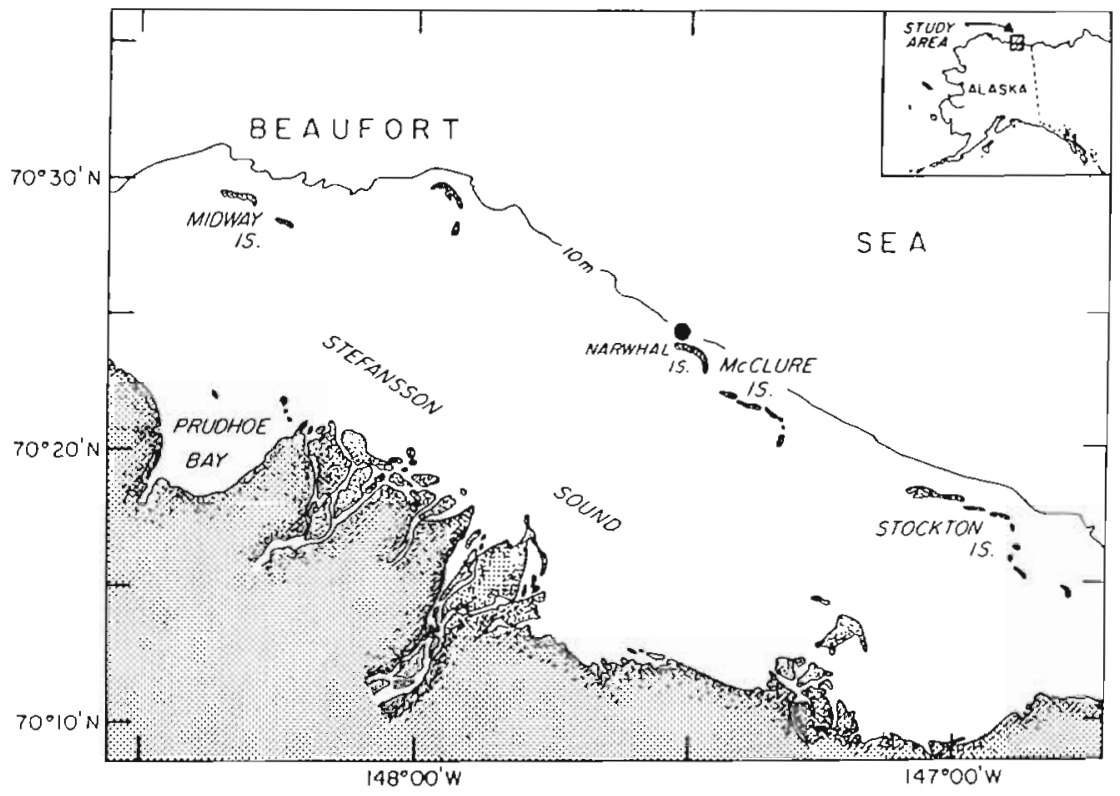

Fig. 1. Southwestern Beaufort Sea, showing the location (black dot) of the Narwhal Island Sea Ice 1980 study site (Redrawn from Kern \& Carey 19831 
Table 2. Pseudalibrotus litoralis. Morphological characteristics used in distinguishing sexes and maturity from the inner continental shelf of the SW Beaufort Sea, spring 1980 (Adapted from Hannan et al. 1979)

\begin{tabular}{|c|c|}
\hline Males & Females \\
\hline $\begin{array}{l}\text { 1. Mature } \\
\text { (a) Very large pair of genital papillae }(>125 \mu \mathrm{m}) \text { located } \\
\text { ventrally on the } 8 \text { th thoracic segment }\end{array}$ & $\begin{array}{l}\text { (a) Fully developed oostegites with setae forming a brood } \\
\text { pouch; may or may not be ovigerous }\end{array}$ \\
\hline $\begin{array}{l}\text { (b) Antennal flagellae long with many short proximal } \\
\text { joints }\end{array}$ & $\begin{array}{l}\text { (b) Shorter antennal flagellae with fewer and longer prox- } \\
\text { imal joints }\end{array}$ \\
\hline $\begin{array}{l}\text { 2. Old immature } \\
\text { (a) Intermediate genital papillae }(125>x<75 \mu \mathrm{m})\end{array}$ & $\begin{array}{l}\text { (a) Moderately developed oostegites with either no or } \\
\text { very short setae }\end{array}$ \\
\hline $\begin{array}{l}\text { (b) Shorter antennae and flagellae with many short articu- } \\
\text { lations }\end{array}$ & (b) Antennal flagellae with few and longer articulations \\
\hline $\begin{array}{l}\text { 3. Young immature } \\
\text { (a) Very small genital papillae }(>75 \mu \mathrm{m}) \text { or small round } \\
\text { protuberances }\end{array}$ & (a) Very small or no oostegites \\
\hline (b) Antennal flagellae with many short articulations & (b) Antennal flagellae with few, long articulations \\
\hline
\end{tabular}

Divers using SCUBA captured amphipods by pushing a rectangular net $(32 \times 11 \mathrm{~cm}$, with a $0.33 \mathrm{~cm} \mathrm{mesh})$ along $10 \mathrm{~m}$ transects adjacent to the ice surface and at the sediment-water interface. The rectangular net also sampled a volume of water just below the ice surface and just above the sediments so the abundance estimates were volumetric. On 13 April, divers sampled dense patches of amphipods living on ice stalactites for 2 samples and the transect for the other 3. This sampling method was used in an evaluation of microspatial variability in the population structure of sympagic Pseudalibrotus litoralis.

Standardized midwater collections of pelagic amphipods were made with a line and pulley system that pulled a $0.75 \mathrm{~m}$ ring net with $0.50 \mathrm{~cm}$ mesh along a $10 \mathrm{~m}$ distance. Divers periodically checked the midwater position of the net. There were 22 sampling dates, from 13 April to 3 June, for the water column habitat, 4 of which were sampled every $2 \mathrm{~h}$ for $24 \mathrm{~h}$ to examine diel differences in the population size structure of Pseudalibrotus litoralis swimming between the ice and the sediments. All amphipods were fixed in $10 \%$ formalin buffered with sodium borate and later transferred to $70 \%$ ethanol for long-term preservation.

Identifications, counts and length measurements were assessed in the laboratory. Using a flexible rule that conformed to the curvature of the body, the total projected length of adult and juvenile amphipods was measured to the nearest mm from the tip of the rostrum to the distal end of the telson.

Two criteria were used in the sex determination of the amphipods: (1) the number and length of the proxi- mal joints in the flagella of the antennae (Sars 1895 , Holmquist 1965); and (2) the presence of genital papillae in males and of oostegites (brood plates) in females. Males were recognized by their more numerous and shorter flagellar joints. When neither of these criteria was observable, individuals could not be sexed and were classified as juveniles.

The maturity of Pseudalibrotus litoralis was estimated according to the criteria in Table 2 (modified from Hannan et al. 1979). In many cases specimens could not be categorized precisely at one maturity stage, so intermediate values were assigned based on the condition of each specimen. For example, maturity of a male with genital papillae between 75 and $125 \mu \mathrm{m}$ was scored at 2.5 , i.e. between the youngest immature (maturity $=3$ ) and older immatures (maturity $=2$ ). Sex ratios, the number of females divided by the number of males, were computed for each date in the ice habitat only. The percentages of mature females with fully developed oostegites in relation to all females and to the total sympagic population were also calculated. Brood size, or number of eggs per females, could not be measured because none of the females captured were carrying eggs or young in the brood pouch.

Size-frequency data were plotted to depict the important spatial and temporal trends in the Pseudalibrotus litoralis population structure. The total population structure from mid-April to early June was plotted for each habitat and compared with a Kolmogorov-Smirnov (K-S) 2-sample test (Sokal \& Rohlf 1981) to determine the spatial variability between the ice, water column, and sediment habitats. Diel differences in 

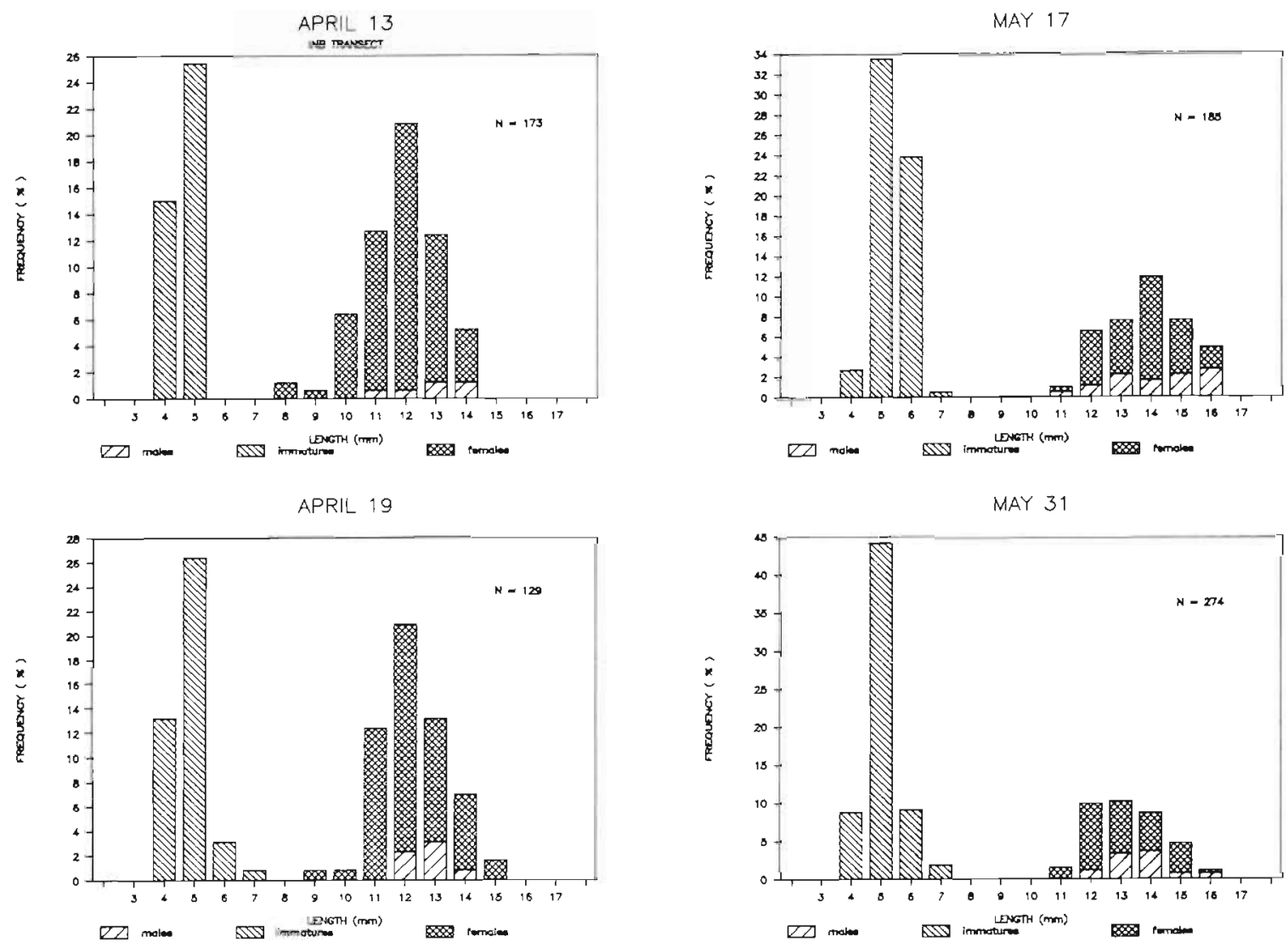

MAY 5
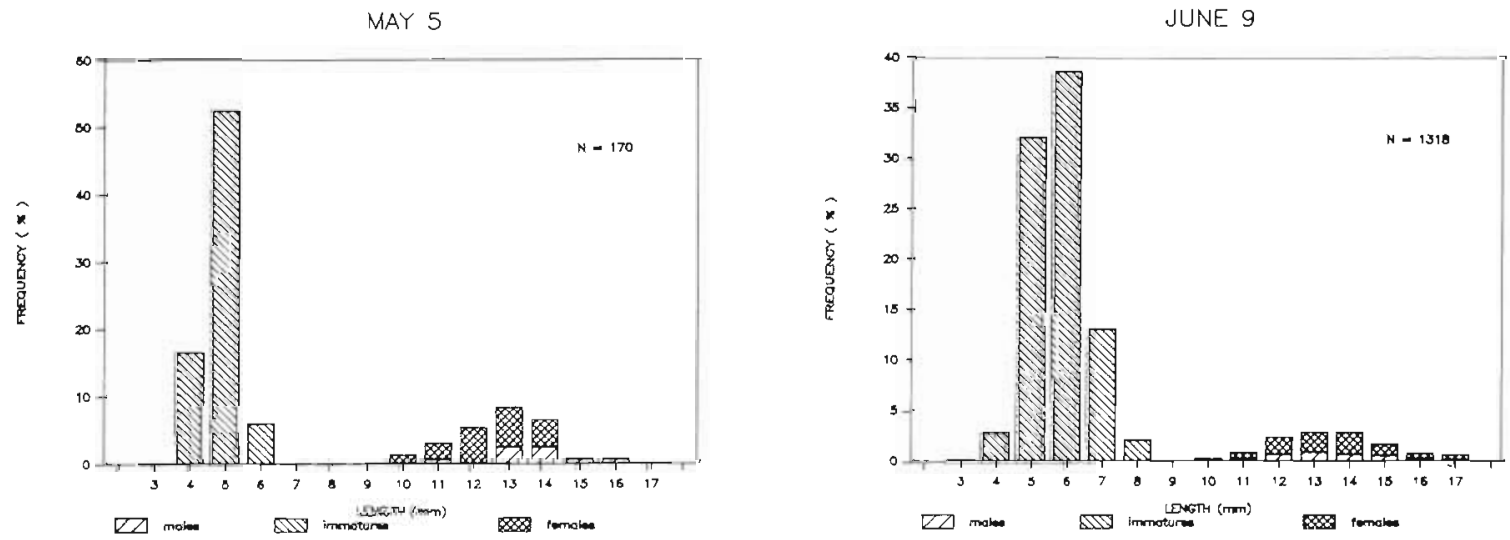

Fig. 2. Pseudalibrotus litoralis, Length-frequency histograms for the sympagic population in the SW Beaufort Sea, spring 1980. Note the bimodal population structure on the 6 sampling dates. INB: Ice Net Benthos collections

population structure for the four $24 \mathrm{~h}$ zooplankton samples, and the changes in size-frequency structure from 13 April to 9 June in the ice habitat, were also tested with K-S tests.

Mean and standard deviations for all major life history traits measured were calculated for males, females and juveniles for all samples taken in the ice transects, and used in an analysis of spring temporal trends in population structure. Microspatial variability was only tested on 13 April with K-S tests to compare the popu- lation structure in dense amphipod aggregations on the stalactites versus that in the ice transect.

\section{RESULTS}

Analysis of the abundance data for all amphipod species shows evidence of strong preferences for the ice or sediment habitat (Table 1). Five amphipod species - Pseudalibrotus litoralis, Halirages mixtus, 
Table 3. Pseudalibrotus litoralis. Number and mean \pm 1 standard deviation (SD) of life history traits in the ice habitat at Narwhal Island, spring 1980

\begin{tabular}{|c|c|c|c|c|c|c|}
\hline & $\begin{array}{l}13 \text { April } \\
\bar{x} \pm S D\end{array}$ & $\begin{array}{l}19 \text { April } \\
\bar{x} \pm \mathrm{SD}\end{array}$ & $\begin{array}{c}5 \text { May } \\
\bar{x}+\mathrm{SD}\end{array}$ & $\begin{array}{l}17 \text { May } \\
\bar{x} \pm S D\end{array}$ & $\begin{array}{l}31 \text { May } \\
\bar{x} \pm S D\end{array}$ & $\begin{array}{c}9 \text { June } \\
\bar{x} \pm \mathrm{SD}\end{array}$ \\
\hline \multicolumn{7}{|l|}{ Number } \\
\hline Juveniles & 56 & 55 & 62 & 112 & 175 & 1165 \\
\hline Males & 6 & 8 & 11 & 19 & 26 & 38 \\
\hline Females (total) & 97 & 65 & 32 & 54 & 73 & 115 \\
\hline Mature females & 1 & 6 & 10 & 19 & 16 & 27 \\
\hline Sex ratio & 16.17 & 8.13 & 2.91 & 2.84 & 2.81 & 3.17 \\
\hline \multicolumn{7}{|l|}{ Length (mm) } \\
\hline Juveniles & $4.19 \pm 0.45$ & $4.36 \pm 0.61$ & $4.48 \pm 0.41$ & $4.83 \pm 0.50$ & $4.59 \pm 0.52$ & $5.35 \pm 1.11$ \\
\hline Males & $12.05 \pm 1.11$ & $12.21 \pm 0.62$ & $13.30 \pm 1.18$ & $13.81 \pm 1.80$ & $13.16 \pm 1.02$ & $13.19 \pm 1.98$ \\
\hline Females & $11.34 \pm 1.17$ & $11.81 \pm 1.15$ & $11.98 \pm 1.03$ & $13.27 \pm 1.35$ & $12.59 \pm 1.17$ & $12.81 \pm 2.27$ \\
\hline \multicolumn{7}{|c|}{ Maturity (cf. Table 2) } \\
\hline Males & $2.58 \pm 0.59$ & $2.31 \pm 0.70$ & $1.55 \pm 0.50$ & $1.71 \pm 0.71$ & $2.14 \pm 0.74$ & $2.28 \pm 0.81$ \\
\hline Females & $2.71 \pm 0.38$ & $2.45 \pm 0.54$ & $2.24 \pm 0.79$ & $2.04 \pm 0.68$ & $2.33 \pm 0.69$ & $2.36 \pm 0.84$ \\
\hline
\end{tabular}

Table 4. Pseudalibrotus litoralis. Results of Kolmogorov-Smirnov 2-sample tests on collections from the ice, water column, and sediment habitats of the Narwhal Island study site, spring 1980

\begin{tabular}{|c|c|c|c|c|}
\hline & $\mathrm{D}_{\text {calc. }}$ & $D_{p}=0.05$ & $D_{p}=0.01$ & Comments \\
\hline \multicolumn{5}{|l|}{ Ice } \\
\hline $13 \mathrm{Apr}$ vs $19 \mathrm{Apr}$ & 0.04 & 0.19 & 0.23 & Accept $\mathrm{H}_{0}{ }^{4}$; NS \\
\hline 19 Apr vs 5 May & 0.32 & 0.21 & 0.25 & Reject $\mathrm{H}_{0}{ }^{b} ; \cdots$ \\
\hline 5 May vs 17 May & 0.33 & 0.19 & 0.23 & Reject $\mathrm{H}_{0} ; \cdots$ \\
\hline 17 May vs 31 May & 0.17 & 0.17 & 0.21 & Reject $\mathrm{H}_{0 i} \cdot$ \\
\hline 31 May vs 9 Jun & 0.25 & 0.13 & 0.16 & Reject $\mathrm{H}_{\circ i} \cdots$ \\
\hline \multicolumn{5}{|l|}{ Patch vs Transect } \\
\hline $13 \mathrm{Apr}(1 \& 2)$ vs $13 \mathrm{Apr}$ (transect) & 0.34 & 0.20 & 0.24 & Reject $\mathrm{H}_{\mathrm{o}} \cdots$ \\
\hline \multicolumn{5}{|l|}{ Total habitat tests } \\
\hline Ice vs Sediment & 0.52 & 2.43 & 2.92 & Accept $\mathrm{H}_{0} ; \mathrm{NS}$ \\
\hline Ice vs Water Column & 0.23 & 1.47 & 1.76 & Accept $\mathrm{H}_{0} ; \mathrm{NS}$ \\
\hline Sediment vs Water Column & 0.50 & 2.72 & 3.26 & Accept $\mathrm{H}_{\circ i} \mathrm{NS}$ \\
\hline \multicolumn{5}{|c|}{ "The 2 samples are statistically identical and the null hypothesis of K-S tests is accepted (Sokal \& Rohlf 1981) } \\
\hline \multicolumn{5}{|c|}{ - The 2 samples are statistically different at the probability level chosen and the null hypothesis is rejected } \\
\hline
\end{tabular}

Lagunogammarus setosus, Aphereusa glacialis, and Weyprechtia pinguis - were found on the ice in the spring and used it as their principal habitat. $W$. pinguis was the only under-ice species that did not have a residual population in the sediments during the spring of 1980. The other 8 amphipod species, with the exception of a few Oediceros borealis in the water column, were exclusively confined to the sediments. Thus, only a subset of gammarid amphipods from the inner continental shelf use the ice habitat during spring.

Size-frequency analysis of sympagic Pseudalibrotus litoralis demonstrated 2 temporal trends: (1) an increase in abundance from 13 April to 9 June, particu- larly evident for juveniles; (2) a bimodal distribution with only $2.2 \%$ of all specimens between 7.0 and $10.0 \mathrm{~mm}$ long (Fig. 2). Total counts of females actually decreased slightly but the number of mature females increased with time during the spring. The number of males increased 4 -fold from 13 April to 9 June, while the number of immatures increased 20-fold (Table 3).

Based on the results of the 2-sample K-S tests, the ice transect samples of 13 and 19 April were statistically identical but all other temporal comparisons were significantly different (Table 4). Although all the lengthfrequency histograms were bimodal, the results revealed a change at the 0.05 and 0.01 probability 

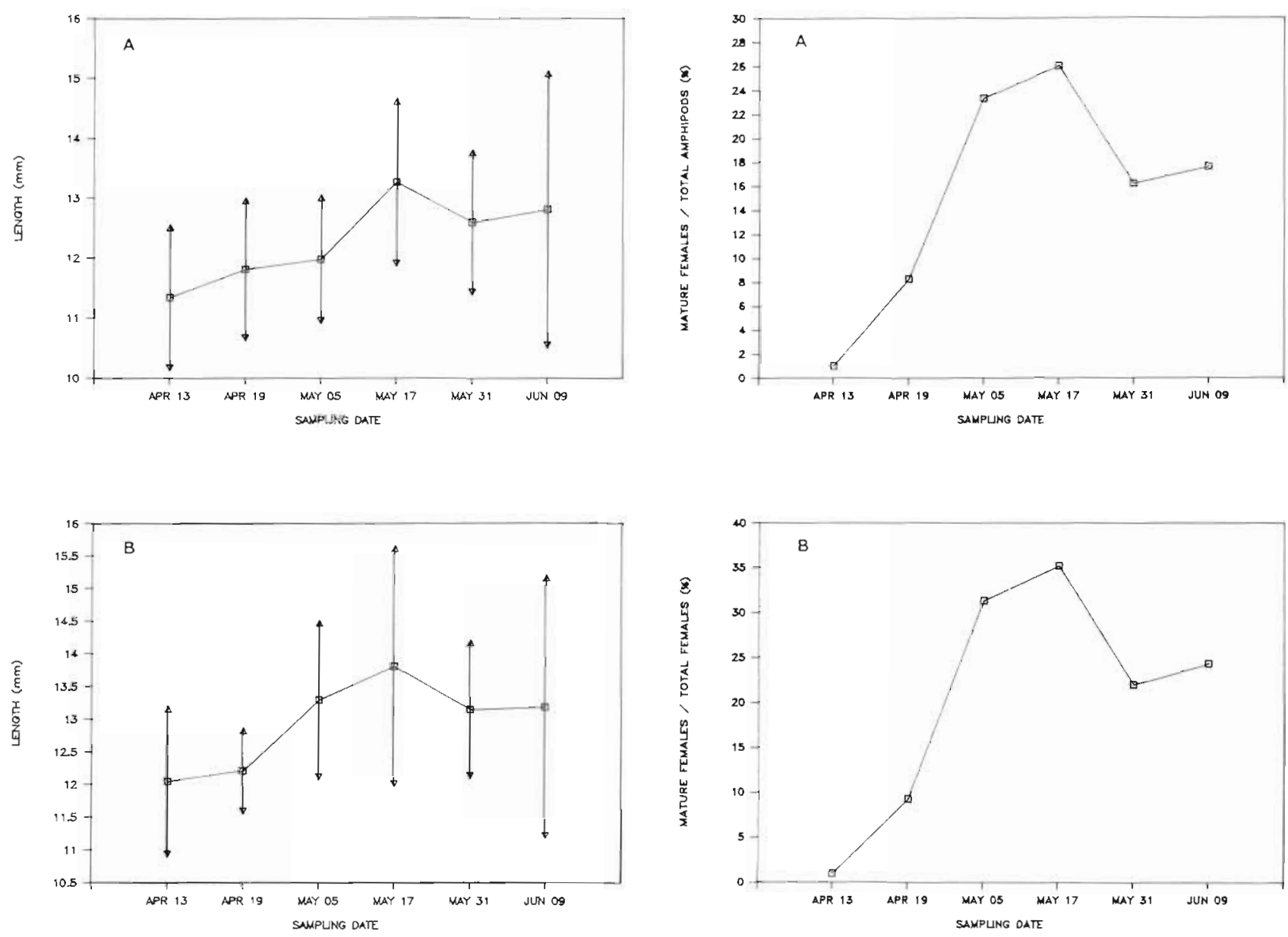

Fig. 3. Pseudalibrotus litoralis. Spring trend of increase in length through time for the sympagic population from the inner continental shelf of the SW Beaufort Sea (mean \pm 1 standard deviation $) .(\mathrm{A})=$ Females $;(\mathrm{B})=$ males

levels in the population structure from 19 April to 9 June, especially in the length of juveniles and adults and in the number of juveniles.

There was a dramatic change in the sex ratio of the ice population of Pseudalibrotus litoralis during the spring, with a 5-fold decrease from 13 April to 31 May (Table 3 ). This change resulted from the combined effect of an overall decrease in the number of females and a corresponding increase in the number of males.

Finally, 3 other life history parameters varied during the sampling period. The general trends for males, females, and juveniles indicated an increase in length through time with a peak between 17 and 31 May (Fig. 3). However the results of regression analysis of size $(y)$ against time $(x)$ only showed significant correlation $\left(r^{2}=0.66\right)$ for females. The change in mature females as a percentage of the total amphipods and as a percentage all other females resulted in similar plots peaking on 17 May (Fig. 4). Thus, these 3 life history

Fig. 4. Pseudalibrotus litoralis. Temporal trend in (A) percentage of mature females to total amphipods; and (B) percentage of mature females to total females for the sympagic population at the 1980 Narwhal Island ice station

parameters showed the same temporal trend in the ice habitat during the spring.

There were some notable differences in population structure between the 2 dense, under-ice amphipod aggregations and the 3 standard ice transect samples taken on 13 April 1980 (Fig. 5). The K-S test between the size-frequency structure of the amphipod patch versus the structure of the transect was significant $(p=$ 0.01) (Table 4). Furthermore, a chi-square analysis comparing the number of mature females in the patch $(n=43)$ to that in the transect $(n=1)$ was significant for the 2 sub-habitats sampled on the same date $\left(x^{2}=144\right.$; d.f. $=1 ; p=0.005$ ). Finally, the ratio of females to males was 5.16 in the aggregation compared to 16.17 for the transect on 13 April. Thus, dense aggregations of amphipods in the ice were characterized by more males, more mature females and in general, a different size-frequency structure than the transects sampled on the same date at the same fixed ice station. 
Because the number of Pseudalibrotus litoralis in the sediments and in the water column was low, detailed temporal trends could not be analyzed for these 2 habitats. However, total abundance for the sampling period was large enough to permit a statistical comparison among the 3 habitats. Using standardized abundance data for the 3 habitats, K-S 2-sample tests indicated no statistical difference $(p=0.01)$ in the bimodal population structure of $P$. litoralis among the 3 habitats of the inner continental shelf of Narwhal Island (Table 4).

Diel changes in population structure of Pseudalibrotus litoralis in the water column habitat were also investigated. The $24 \mathrm{~h}$ samples were taken on 30 April to 1 May, 7 to 8 May, 19 to 20 May and 2 to 3 June. Results of 2sample $\mathrm{K}$-S tests for all sampling dates indicated no significant difference between day and night size-frequency structure. We found the same result when a total day-night test was performed for all four $24 \mathrm{~h}$ samples combined. However, the abundance of juveniles and adults was higher at night in samples taken on 30 April to 1 May and on 7 to 8 May (Carey et al. 1984).

\section{DISCUSSION}

Three major caveats affect the interpretation of our data: (1) because it is logistically difficult to sample year-round in the Arctic, our sampling was limited to only part of the amphipod life cycle; (2) we had no indication of the brood size of Pseudalibrotus litoralis in the southwestern Beaufort Sea because none of the females captured was carrying eggs or young; and (3) the results of the microspatial analysis implied large differences in the population structure of a transect compared to a dense aggregation; therefore, using transect data may have affected our results. The lack of young in the brood pouch may have occurred because amphipod females in the Arctic usually carry their eggs in the summer and their young in the fall and winter (Steele 1961), or because they released their young upon capture or preservation (J. Percy pers. comm.). Recent work in the Eastern Canadian Arctic has shown that $P$. litoralis females are rarely captured with embryos, eggs or young in the brood pouch (Cota \& Watson pers. comm.).

Nonetheless, our data provide reasonable insight into the life cycle of Pseudalibrotus litoralis in the shallow SW Beaufort Sea. The bimodal population structure, with one large peak between 4.0 and $6.0 \mathrm{~mm}$ and another in the size range 11.0 to $14.0 \mathrm{~mm}$, has been used as evidence for semelparous 2 yr life cycles (Schneider 1891, Steele 1961, Kanneworff 1965, Rakusa-Suszczewski 1972, Rakusa-Suszczewski \& Klekowski 1973, Kulikov 1980, Sagar 1980, Cross 1982).
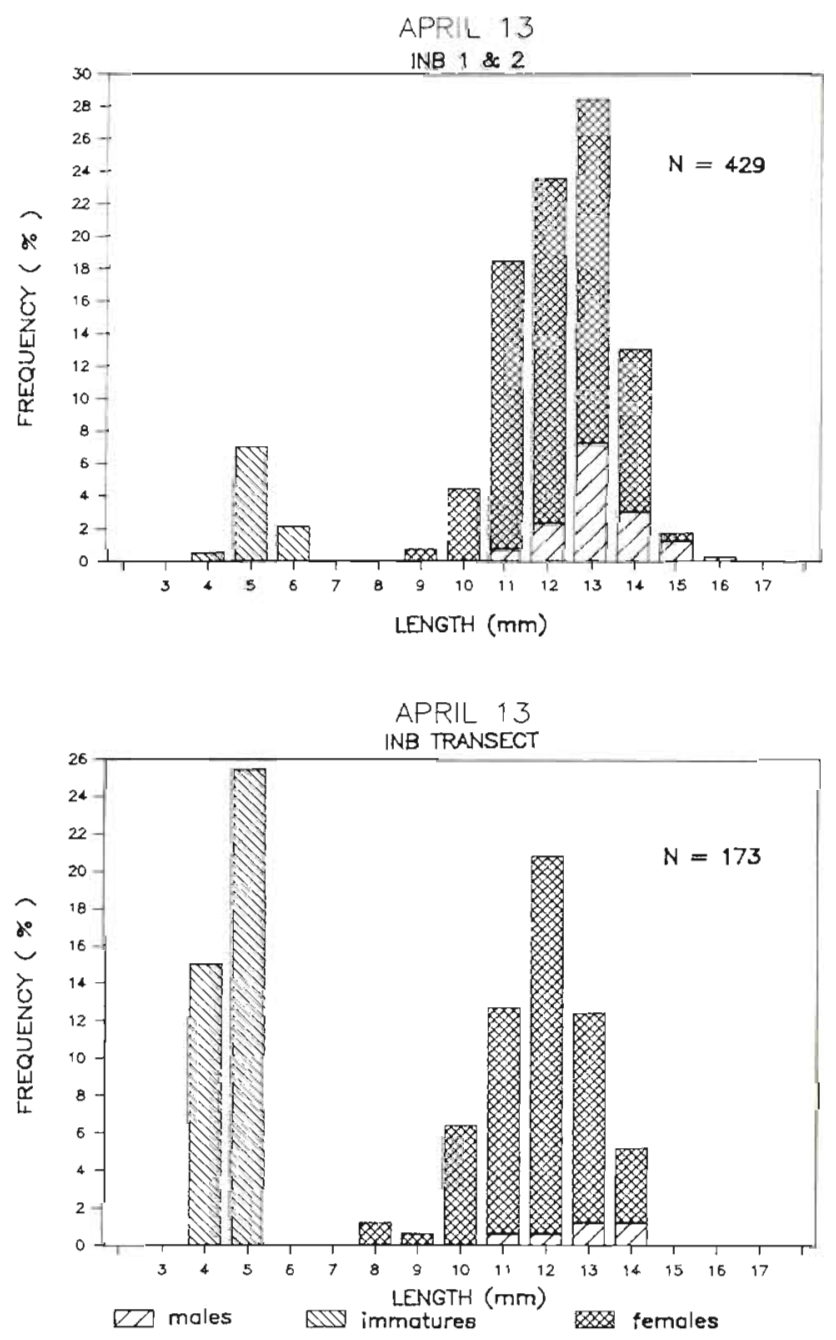

Fig. 5. Pseudalibrotus litoralis. Length-frequency histograms comparing the population structure in dense amphipod aggregations (13 April, INB $1 \& 2$ ) to the structure of a standard ice transect (13 April, INB transect) at the Narwhal Island ice station, spring 1980. INB: Ice Net Benthos Collections

The small juveniles were either newly released $(3.0$ to $<5.0 \mathrm{~mm})$ or at most 2 or 3 mo old $(5.0$ to $<7.0 \mathrm{~mm})$. They could not have been spawned by the older and larger (10.0 to $14.0 \mathrm{~mm})$ immatures found simultaneously. Mature females of $13.5 \mathrm{~mm}$ or more with fully developed oostegites and mature males of 14.0 to $17.0 \mathrm{~mm}$ were rare in our samples. They probably died after spawning (females) or mating (males).

Our data suggest the following life cycle: (1) release of young $(3.0$ to $6.0 \mathrm{~mm})$, death of mature adults, and growth of young and old immatures in the spring (Year 1); (2) growth of juveniles, young immatures, and maturation of older immatures in the summer (Year 1); (3) new adults congregate under the ice in the fall for mating, with continued growth of juveniles to young immatures and of young immatures to older immatures 
(Year 1); (4) overwintering of new adults and all male and female immatures (Year 1); (5) adults release new juveniles, die after spawning, and the juveniles of the previous year mature in the spring season (Year 2).

Increase in length of adult females with time and the degree of maturity of males and females also support the 2 yr life cycle hypothesis. Females were the only group to show a significant increase in length through time $\left(0.03 \mathrm{~mm} \mathrm{~d}^{-1}\right)$ but the qualitative analysis for all sexes implied slow growth during the spring. Slow growth is consistent with other research in the Arctic which has shown the prevalence of multiyear life cycles (Steele 1961, Kanneworff 1965, Dunbar 1968, Kulikov 1980, Griffiths \& Dillinger 1981, Cross 1982). Males and females attained an average maturity level of older immature (Table 3). These older male and female immatures were not in the ice to spawn but rather to feed on the early production of diatoms.

Samples from the ice and sediment were collected using the same methods and at the same time during the spring, so the large difference in abundance data (Table 1), with the sediment population being $1 / 15$ that of the ice, could well have resulted from a mass movement of amphipods from the sediments to the ice. This usually sediment-associated population of Pseudalibrotus litoralis moved from the sediments to the ice in the spring to feed on the early carbon source of ice microalgae, diatoms and associated meiofauna (Carey \& Boudrias 1987). The results are concordant with data from the Central Arctic Basin where P. litoralis temporarily inhabits the ice in the spring to spawn and gain energy for the upcoming breeding season (Mel'nikov \& Kulikov 1980).

In early April, more individuals were collected midwater during the early morning than later in the day (Carey et al. 1984). This trend decreased with increasing daylength. However, continuous swimming between the ice and the sediments, and bulk population movements to the ice in early spring and to the sediments in early June, may have confounded the diel and temporal trends in the water column habitat. This may have resulted in the lack of statistical difference between day and night population structure.

The increase in the number of young with time, the peak in length of males and females, and the peaks in the percentage of mature females all occurred between 17 and 31 May. This period coincided with the maximum primary production in the ice habitat during the spring of 1980 (Horner \& Schrader 1982, 1984). Also there was a dramatic change in the sex ratio of the sympagic population between 5 and 17 May, suggesting either that more males were moving up to the ice habitat to feed on its early carbon source or that more females may have died after spawning.

Pseudalibrotus litoralis temporarily inhabit the ice during spring and profit from the early bloom of microalgae, diatoms, and harpacticoid and cyclopoid copepods (Carey \& Boudrias 1987). They feed on meiofaunal crustaceans and dead or dying ice amphipods early in spring and on ice algae during the latter part of the season. This life history strategy may permit a higher survival of recruits owing to the concentrated food available, and additional nutrition for the older immatures preparing for fall mating. $P$. litoralis life history patterns in the ice, water column, and sediment habitats, and its feeding ecology, thus support the 'early carbon hypothesis' (Dunbar 1977).

Acknowledgements. Many thanks to R. E. Ruff, P. H. Scott, K. R. Walters, J. C. Kern, J. Trautman-Nielsen, W. Savidge for their help in the field and in the laboratory. SCUBA diving services were provided by G. F. Smith, J. Dougherty, and R. Poirot of Coastal Environmental Co., Bellingham, Washington J. J. Beatty, R. R. Hessler, E. W. Hogue, C. B. Miller, G. L. Taghon and 2 anonymous reviewers reviewed an earlier draft of this paper and their comments are greatly appreciated. Field work was supported by the Minerals Management Services through interagency agreement with the National Oceanic and Atmospheric Administration as part of the Outer Continental Shelf Environmental Assessment Program. The first author was supported by a Québec provincial F.C.A.C. Post-Graduate Scholarship.

\section{LITERATURE CITED}

Andersen, O. G. N. (1977). Primary production associated with sea ice at Godhavn, Disko, West Greenland. Ophelia 16 $205-220$

Apollonio, S. (1961). The chlorophyll content of Arctic sea ice. Arctic 14: $197-206$

Apollonio, S. (1965). Chlorophyl] in Arctic sea ice. Arctic 18 118-122

Barnard, J. L. (1959). Epipelagic and under-ice Amphipoda of the Central Arctic Basin. Geophysical Research Papers 63: 115-129

Bradstreet, M. S. W., Cross, W. E. (1982). Trophic relationships at high Arctic ice edges. Arctic 35: 1-12

Buck, K. R., Garrison, D. L. (1983). Protists from the ice-edge region of the Weddell Sea. Deep Sea Res. 30: 1261-1277

Carey, A. G., Jr (1985). Ice fauna: Arctic. In: Horner, R. A. (ed.) Sea ice biota. CRC Press, Inc., Boca Raton, Florida, p. $173-190$

Carey, A. G., Jr, Montagna, P. A. (1982). An Arctıc sea ice faunal assemblage; a first approach to the definition and the source of the underice meiofauna. Mar. Ecol. Prog. Ser 8: $1-8$

Carey, A. G., Jr, Boudrias, M. A., Kern, J. C., Ruff, R. E. (1984). Selected ecological studies in continental shelf benthos and sea ice fauna in the Southwestern Beaufort Sea. U.S. Dept Commer. NOAA, OCSEAP Final Rep. 23: 1-164

Carey, A. G., Jr, Boudrias, M. A. (1987). Feeding ecology of Pseudalibrotus (=Onisimus) litoralis (Crustacea: Amphipoda) on the inner continental shelf of the SW Beaufort Sea. Polar Biol. 8: 29-33

Cross, W. E. (1982). Under-ice biota at the Pond Inlet ice edge and adjacent fast ice areas during the spring. Arctic 35: $13-27$ 
Dunbar, M. J. (1968). Ecological development in polar regions. Prentice-Halle, Englewood Cliffs, New Jersey

Dunbar, M. J. (1977). The evolution of polar ecosystems. In: Llano, G. E. (ed.) Adaptations within Antarctic ecosystems. Proceedings of the third SCAR Symposium on Antarctic Biology, Smithsonian Institution, Washington, D.C., p. 1063-1076

Grainger, E. H., Hsiao, S. I. C. (1982). A study of the ice biota of Frobisher Bay, Baffin Island, 1979-1981. Canadian MS Report of Fisheries and Aquatic Sciences, No. 1647: 1-128

Griffiths, W. B., Dillinger, R. E. (1981). Beaufort Sea barrier island-lagoon ecological processes studies: final report, Simpson lagoon. In: NOAA/OCSEAP Final Report of Principal Investigators Environmental Assessment of the Alaskan Continental Shelf, Vol. 8: Biological Studies, p. $1-198$

Gulliksen, B. (1984). Underice fauna from Svalbard waters. Sarsia 69: $17-23$

Hannan, C. A., Hulberg, L. W., Mawn, K. M., Kellogg, M. G., Nybakken, J. M. (1979). A study to develop standard procedures for life-history analyses of benthic invertebrates for biological monitoring in marine and estuarine environments. California State Water Resources Board, Publication No. 63: 1--398

Holmquist, C. (1965). The amphipod genus Pseudalibrotus. J. Zool. Syst. Evol. 3: 19-46

Horner, R. A. (1985). Ecology of ice microalgae. In: Horner, R. A. (ed.) Sea ice biota. CRC Press, Boca Raton, Florida, p. $147-157$

Horner, R. A., Schrader, G. C. (1982). Relative contributions of ice algae, phytoplankton and benthic microalgae to the primary production in nearshore regimes of the Beaufort Sea. Arctic 35: 485-503

Horner, R. A., Schrader, G. C. (1984). Beaufort Sea plankton studies: winter-spring studies in Stefansson Sound and off Narwhal Island, November 1978-June 1980. U.S. Dept. Commer. NOAA, OCSEAP Final Rep. 25: 193-325

Hsiao, S. I. C. (1980). Quantitative composition, distribution, community structure, and standing stock of sea ice microalgae in the Canadian Arctic. Arctic 33: 768-793

Kanneworff, E. (1965). Lifecycle, food, and growth of the amphipod Ampelisca macrocephala Liljeborg from the Oresund. Ophelia 2: 305-318

Kern, J. C., Carey, A. G., Jr (1983). The faunal assemblage inhabiting seasonal sea ice in the nearshore Arctic Ocean with emphasis on copepods. Mar. Ecol. Prog. Ser. 10: 159-167

Knox, G. A., Lowry, J. K. (1977). A comparison between the benthos of the Southern Ocean and the North Polar Ocean with special reference to the Amphipoda and Polychaeta. In: Dunbar, M. J. (ed.) Polar oceans. The Arctic Institute of North America, Calgary, Alberta, p. 423-462

Kulikov, A. S. (1980). The ecology of two species of gammarids (Amphipoda: Gammaridea) and a mysid (Mysidacea) in the cryopelagic biocoenosis of the Central Arctic Basin. In: Vinogradov, M. E., Mel'nikov, I. A. (eds.) Biologiya Tsentral'nogo Arkticheskogo Basseina. Akademiya Nauk
SSSR, Moscow, Nauka Publishing House (Translated by the Translation Bureau, Dept. of the Secretary of State of Canada, 1983), p. 111-118

Mel'nikov, I. A., Kulikov, A. S. (1980). The cryopelagic fauna of the Central Arctic Basin. In: Vinogradov, M. E. Mel'nikov, I. A. (eds.) Biologiya Tsentral'nogo Arkticheskogo Basseina. Akademiya Nauk SSSR, Moscow, Nauka Publishing House (Translated by the Translation Bureau, Dept. of the Secretary of State of Canada, 1983), p. 97-111

Montagna, P. A., Carey, A. G., Jr (1979). Distributional notes on Harpacticoida (Crustacea: Copepoda) collected in the Beaufort Sea (Arctic Ocean). Astarte 11 117-122

Rakusa-Suszczewski, S. (1972). The biology of Paramoera walkeri Stebbing (Amphipoda) and the Antarctic sub-fast ice community. Polskie Arch. Hydrobiol. 19: 11-36

Rakusa-Suszczewski, S., Klekowski, R. Z. (1973). Biology and respiration of the Antarctic Amphipoda (Paramoera walkeriStebbing) in the summer. Polskie Arch. Hydrobiol. 20: $475-488$

Sagar, P. M. (1980). Life cycle and growth of the Antarctic gammarid amphipod Paramoera walkeri (Stebbing, 1906). J. R. Soc. New Zealand 10: 259-270

Sainte-Marie, B. (1984). Morphological adaptations for carrion feeding in four species of littoral and circalittoral lysianassid amphipods. Can. J. Zool. 62: 1668-1674

Sancetta, C. (1981). Oceanographic and ecologic significance of diatoms in surface sediments of the Bering and Okhotsk seas. Deep Sea Res. 28: 789-817

Sars, G. O. (1895). Amphipoda. An account of the crustacea of Norway. Bergen. Mus. Alb. Camm. Christian. and Copenhagen, Vol. 1: 1-711

Schneider, I. A. (1891). Fortplantningstiden of livarigheden hos Amphipoderne. Tromso Museums Aarhefter 14: 59-74

Sokal, R. R., Rohlf, F. J. (1981). Biometry the principles and practice of statistics in biological research, 2 nd edn. W. H. Freeman \& Co., New York

Steele, D. H. (1961). Studies in the marine amphipoda of Eastern and Northeastern Canada, Ph. D. thesis, McGill University, Montreal, Quebec, Canada

Thomson, D. H. (1984). Distribution, production, and ecology of gray whale prey species. In: Thomson, D. H. (ed.) Feeding ecology of gray whales (Eschrichtius robustus) in the Chirikoff Basin, summer 1982. Rep by LGL Alaska Res. Assc., Inc., Anchorage, for NOAA, Juneau, Alaska, p. $15-74$

Tsurikov, V L. (1980). Mechanisms of sea ice colonization and the possibilities of a microflora developing in it. In: Vinogradov, M. E., Mel'nikov, [. A. (eds.) Biologiya Tsentral'nogo Arkticheskogo Basseina. Akademiya Nauk SSSR, Moscow, Nauka Publishing House (Translated by the Translation Bureau, Dept. of the Secretary of State of Canada, 1983), p. 119-137

Whitaker, T M. (1977). Sea ice habitats of Signy Island (South Orkneys) and their primary productivity. In: Llano, G. A. (ed.) Adaptations within Antarctic ecosystems. Proceedings of the third SCAR Symposium on Antarctic Biology. Smithsonian Institution, Washington, D.C., p. 75-89 